\title{
Political Power and the Globalizing Spread of Populist Politics
}

There has been growing interest in populism since the election of Donald Trump and Brexit in 2016. Academic discussion of populism is, of course, not new (Ionescu and Gellner 1969). There is now an extensive literature about populisms past and present and for several parts of the world (see Mudde and Kaltwasser 2017). Recent interest in this phenomenon has been sparked by the ongoing rise of populist power - if a major facet of power is seen as populists entering governments. These successes raise the question whether the current wave of populism is part of a wider realignment of political power, perhaps beyond left and right, and if so, what the causes of this realignment are. This paper will argue that there has, indeed, been such a realignment, which will be illustrated here by reference to four countries: the United States (US), Sweden, India and China. The rationale for focusing on these four cases has been made on a number of occasions, but briefly, they can be seen as being most dissimilar cases among advanced democracies (Pontusson 2005) and among the major models - an imperfect democracy in India and an authoritarian regime in China - for developing countries (Bardhan 2010). Despite this variety, these four countries have seen advances of right-wing populist forces. This paper argues that the recent success of populism in all four countries can be attributed not - as dominant explanations would have it - to economic and cultural power, but rather primarily to political power. In particular, in all four countries, there are growing constraints on the state's provision of citizenship rights which leads to a 'my nation first' politics of 'the people' - defined exclusively - against elites, and which seeks to prioritize the rights of these 'people' within the state. The explanation builds on Mann's theory of power and his account of citizenship struggles vis-à-vis the state, extending these struggles into the $21^{\text {st }}$ century. And while this explanation applies to all four cases, there are important differences between them which, it will be argued, illuminate the wider dynamic of right-wing populism. 
There have been a number of attempts to explain the rise and strength of right wing populism. Left-wing populism falls outside the scope of this paper because it has not prevailed in the four cases examined here, though there are important left-wing populist currents, such as the unsuccessful presidential run of Bernie Sanders in the US or those who seek a return to Maoist egalitarianism in China (though it also hard to label this as leftist, as we shall see). The most common explanations have linked populism to the recent global economic crisis (Judis 2016, 2018), or to increased migration or the Islamist threat or other cultural explanations such as social status anxiety (Gidron and Hall 2017) or identity politics (Fukuyama 2018). A review of these explanations is beyond the scope of this paper (but see Gidron and Bonikowski 2017), but instead of economic and cultural power, the main focus here will be on political power which can be used to explain populism in the four cases here - and perhaps beyond.

This paper argues that while cultural and economic forces are important, there is also a more basic explanation that concentrates on political power: growing constraints on the ability to provide citizenship rights which entail that populists aim to restrict these rights to their own ingroups. This constraint also fosters resentment towards cosmopolitan elites that pay insufficient heed to this demand. Exclusion of out-groups and anti-elitism are two elements in widely accepted definitions of right-wing populism; the third is that in-groups seek stronger political representation, to equate 'the people' with the 'general will' (Mudde 2007). It is this third element where political conflict is played out as populists seek more power. Mueller (2016) has coined the pithy phrase 'we are the 100\%' which sums up all three elements since the $100 \%$ excludes others, is aimed against elites, and seeks more representation for the alleged $100 \%$. The argument here will be that once it is recognized that this is primarily a political rather than 
an economic or cultural struggle, it becomes possible to provide an accurate diagnosis of populism and its prospects.

The paper will proceed in four stages: first, it will distinguish populism from related phenomena and offer an explanation that departs from other recent explanations. Next, it will chart the origins and recent successes of populism in each of the four cases. It will then highlight some of their differences and similarities, and argue that a fundamental realignment of political power beyond left and right is taking place. Characterizing this realignment also makes it possible to pinpoint the distinctive social changes which buttress the current wave of populism as opposed to its previous incarnations. Finally, the paper will offer support for seeing populism as part of a wider globalizing phenomenon which is likely to gain strength in the future.

\section{An Exclusionary People and Its Enemies}

The recent resurgence of populism, particularly in America but also in Europe, is sometimes attributed to the economic crisis in the wake of the Great Recession of 2008 (Judis 2016). But countries which have weathered the economic crisis well, such as the Nordic countries and India, also have strong right-wing populist parties. Even if populism is blamed more on longterm economic difficulties, or populist support is attributed to groups that are particularly strongly affected by economic difficulties, the fit is still poor: support for right-wing populists has not been not confined to those who are worst affected by economic downturns (Mudde 2007, pp. 119-37). Heiskala, who has also (albeit very briefly) drawn on Mann's conceptualization of power in explaining populism, points out (2018, p.334) that economic power can also be seen as being at the root of populism in so far as, after the collapse of communism, the economic position of lower economic strata has become more precarious. Yet 
in view of the wide range of economic up's and down's for different strata in the countries examined here (and beyond), this growing sense insecurity can, as we shall see, be more precisely attributed to the uncertainties and limits surrounding the benefits of citizens vis-à-vis states, or political power. Indeed, it has been argued that in Europe and the US, it is not the least well-off but those with status anxieties just above this group who are most prone to populism (Gidron and Hall 2017). Again, however, it is difficult to see how status anxious groups can play this role in countries where highly varied electorates and economic strata support populism. Cultural explanations invoking 'identity’ have also been offered (Fukuyama 2018) but for countries with quite different levels of immigration (including very little) and despite that some countries have had high levels of immigration without populism (such as Europe in the late 1950s and 60s).

Without reviewing this rapidly growing literature, this paper will offer an account with a different explanation for the four cases examined here. This explanation rests on the idea that there have been limits on strong economic growth since the end of the postwar 'Golden Age' in high-income countries and the rise of economic inequalities in emerging economies (Crouch 2004). But these economic limits do not cause right-wing populism in a direct way; due to economic hardship. Instead, the main dynamic of social development during the $20^{\text {th }}$ century can be seen in terms of pressures to expand the scope of citizenship rights, an idea developed by (Mann 1988, 2013) drawing on T.H. Marshall as part of a broader explanation of globalizing processes. The struggle for citizenship rights and obtaining power via inclusion in the state, over time, has included civil, political and social rights (though not necessarily in stages; in Germany, for example, social rights came before civil and political rights). Social citizenship rights have been the last to be realized fully in welfare states. Yet in recent decades, with diminished growth in high income countries and growing inequalities at least in China and 
India, they face increasing constraints to their expansion or curtailment. And social rights also include the right to a participate in a shared culture.

Mann's idea of citizenship rights has also been developed by other sociologists. Turner's (1986) account of citizenship rights can be pictured as an expanding circle of rights that includes ever deeper and greater inclusion, as for example recently with children's rights and more recently still with animal rights. Walby (2009) makes women's and gender rights a particular focus of her analysis of citizenship rights, from the right to vote to rights within the family or household. Further, it can be noted that citizenship rights also applies, though in a distinctive way, to China: Andreas (2019), for example, also drawing on Marshall's ideas like Mann, has shown that social citizenship took the form of 'industrial' citizenship, guaranteed via the workplace.

Yet right-wing populists seek to seek to curtail the citizenship rights of those who are not part of the 'people', such as minorities or migrants. 'Outsiders', according to populists, are to be excluded from sharing in the benefits provided by the nation-state, whether these benefits consist of social, political or civil rights - and the denial of the cultural part of social citizenship can be a pretext for restricting other rights, as we shall see. This is a good place to distinguish populism from nationalism: Gellner's (1983) theory of nationalism concerns the drive towards the congruence between state and nation. The merits and shortcomings of Gellner's theory have been much debated (see, for example, Malesevic and Haugaard, 2007), but populism goes beyond nationalism: it is not just that a homogenous culture must be created, but the nation should also actively seek to exclude certain groups; 'ultranationalism'. Ultranationalism is not simply nativism, the return to a core of the nation, but rather 'leads to a devaluing of and aggression towards the "they group"” (Zhao 2004: 253). Ultranationalism aims to exclude the 
'they group', which sets this form of nationalism apart from its precursor. Moreover, this exclusionary form of nationalism can be oriented towards a domestic or a foreign 'they group', which brings us back to the geopolitical dimension of populism.

Gellner's view of nationalism does not have a geopolitical dimension, while Mann's does (Mann 1986: 27-8; removed for review). Changing geopolitical fates add an 'outside-in' dimension of legitimating populist demands for citizenships rights and excluding 'others'. Thus rising powers like China and India generate increasing expectations for expanding the benefits of citizenship rights whereas relatively declining or 'threatened' ones like Sweden and the US generate demands to preserve them more exclusively for those who are thought to have traditionally 'deserved' them. In the US, this applies to those who are seen as having contributed to a productivist ethic while in Sweden it applies to protecting the culture of those who are seen to have built the peoples' home. In India, Hinduism is seen as the superior culture that is alleged to have led to India's greatness and independence and that should be strengthened against 'others' (especially Muslims). In China, these rights should be expanded for those who remade the country into an economic and civilizational powerhouse after its 'century of humiliation' at the hands of other powers during the $19^{\text {th }}$ century.

In all four cases then, right wing populists want to restrict citizenship rights to 'the people', but how citizenship is construed as belonging to an exclusive people differs: in China, it is citizenship of the virtuous 'masses' or the Han majority. (In China, citizenship rights are formally granted, but in practice controlled by the party-state.) In Sweden, it is the social citizenship of those who built the 'people's home'; in the US, citizenship is seen as a prerogative for the productive 'core', which is given a nativist tinge; and in India, citizenship belongs exclusively to the virtuous religious majority. These are 'the people', and against the 
backdrop that there are limited resources to provide (especially social) citizenship, who should be excluded also varies. For the US and Sweden, it is immigrants and the 'undeserving'. In India, exclusion aims at Muslims and less fervent Hindus or secularists. In an ethnically (relatively) homogeneous China, exclusion aims at those who do not contribute to a greater China or undermine its distinctive civilization. The Chinese criterion may seem vague; but it fits with a long-standing tradition in China whereby the virtue of citizens is considered in terms of contributing to the public good - as is the virtue of rulers who maintain public order. Further, in the cases of India and China, it is not so much that outsiders threaten this order; rather, less virtuous groups do not belong among those who contribute to a superior civilization.

Whereas the process of nation-state formation expanded these rights over the course of modern political history, in recent decades, as limits to the resources of expanding citizenship rights have emerged, elites can be blamed for not safeguarding the citizenship rights exclusively for the true 'people' or extending them too far by making them available to undeserving 'others'. Elites are regarded as self-serving rather than serving the needs of 'the people'. This feature of populism also applies to left wing populism, where wealthy economic elites are attacked as not part of the 'people'. But in the case of right wing populism, the elites that are attacked are political elites (and the media elites that support them), also because they are too oriented to serving the global economy rather than preserving resources for the nation's 'people'. Both 'foreigners' and the 'undeserving' are thus encroaching upon the rights of 'the people'.

The key difference between right wing populism as against extreme or radical right-wing politics or right-wing nationalism is that right-wing populism is anti elite. 'People' challenge how elites distribute resources; they believe that corporate and financial elites, self-interested political elites, and multi-cultural professional and media elites do not put the nation's 'people' 
first. Political elites and their media supporters are seen to promote a pluralistic culture rather than promoting 'my people first'. But populism also goes beyond right and left: whereas the drive to extend rights was often an egalitarian one or one which sought greater inclusion and deeper and broader rights, populism partly extends this process - more rights for 'the people' - but also constrains it in seeking fewer or lesser rights for those who are not part of 'the people'. In short, populism seeks a selective extension of rights, for 'my people first', strengthening the rights of some and weakening those of 'others'.

Right-wing populism can thus be seen in terms of citizenship rights and inclusion and exclusion: Vertically, there is the demand against elites for the greater inclusion of a certain people into the state; horizontally, the aim is the exclusion of 'others' who are not part of the people. This fits with the definition of right-wing populism if it is added that the vertical inclusion demand and the horizontal exclusion demand are related insofar as the political demands or struggles here are for a different distribution of citizenship rights, excluding the powers of some groups horizontally and taking power away vertically from elites that favour the existing distribution of rights. Right-wing populists support leaders and parties that seek to greater power for the 'people'. And although, again, left-wing populism is outside the scope of the four cases examined here, this account potentially encompasses left-wing populism insofar 'my people first' is directed against globalizing economic forces that threaten workers' and citizens' social rights and against elites who are seen to benefit disproportionally from these very same globalizing economic forces.

Putting the 'people's' nation first also entails foreign threats, stemming from the enemies that are causing America's decline, the threats from multi-culturalism that are diluting Swedish culture, a threat from Islamic neighbours in India, and those who fail to acknowledge China's 
greatness or have harmed its national pride, like the Japanese. These are not abstract threats; people see them in concrete terms, in the foreign competition that is alleged to unfairly take away American jobs, in minarets that are culturally alien in Sweden, in Muslims that threaten Hindu women, or Japanese businesses and products that should be boycotted in the light of atrocities committed against Chinese during the war. Terrorists also constitute an external threat in all four cases. But in the US and Sweden, national decline is part of a declining West, whereas in India and China, a rising East should be given more of its due. Elites in all four cases are accused of overlooking their nations' interests: economic elites favour the international rather than national economy, media and intellectuals are not attuned enough to the culture of the common people, and political elites do not provide enough security and benefits for their 'people' (Brubaker 2017).

To summarize, the explanation here follows a mainstream tradition in political sociology whereby different classes-citizens and social movements make demands on the state; they struggle to be represented in the state (Collins 1999, Mann 2013). Collins has summarized Mann's broader analysis of political power as follows: 'In the late twentieth century and into the next,' left/right or class conflict as 'forms of group mobilization have not been superseded, but they have been joined by many more movements: race and ethnicity (construed in various ways), gender, sexual preference, student, environmentalist, animal rights, anti- and proreligious movements. All these operate under the umbrella of the overarching, societypenetrating state, and thus make an appeal to the same large public consciousness and to state enforcement of their demands' (2006: $30-1)$. In the $19^{\text {th }}$ and $20^{\text {th }}$ centuries, successive demands and struggles for citizen-rights vis-à-vis the state have been won, but in the $21^{\text {st }}$ century, against the backdrop of the constraints of distributing more resources to all, limits are shaping political power: vertically, elites are not responsive enough to giving the 'people' their due (see also 
Mair 2013), and horizontally they do not exclude other groups enough. The struggle for rights to be included in the state has continued to be bottom-up but recently, rather than expanding citizenship, seeks to exclude 'enemies' from the state. 'Enemies' evokes Carl Schmitt, and perhaps that is appropriate for a period in which social development increasingly focuses on political rather than economic and cultural conflict and power. Against this background, we can turn to the specific political conflicts that are shaping 'my people first'.

\section{A Peoples' Home only for 'Swedes'?}

The roots of the Sweden Democrats are in neo-Nazi groups that emerged in the 1980s and in an anti-tax party that rose briefly and fell back into obscurity in the 1990s (Baas 2014). Their rise as a party with a strong presence in parliament is more recent. Although they had some successes in local and regional elections in the early 2000s, they only crossed the threshold to enter the national parliament in 2010, and gained $12.9 \%$ to become the third largest party in 2014 and continued gains in 2018 with 17.5\%. Over time, the Sweden Democrats have tried to shed their early associations with neo-Nazi organizations and widen their appeal as a mainstream party. Yet like other populist parties, they are rather fractious and often in the news for scandals, behaving unlike other parties and more like an oppositional movement.

Sweden's parliamentary system and the fact that neither the right nor the left party bloc won a majority in the two most recent elections meant that in theory, the Sweden Democrats were put in a 'kingmaker' position between the two blocs. However, after the 2014 election, the Social Democrats and the Conservatives (Moderaterna) made an alliance to exclude them from power. This meant that the Sweden Democrats could claim that a 'backroom deal' on the part of the 'establishment' has kept them from obtaining the power that is their due. Since 2014, the government also began to adopt a different tactic, putting in place tougher immigration laws in 
2016, and this has since served to outflank the appeal of the Sweden Democrats' anti-immigrant stance. But in recent years, some Conservatives and members of other parties have started to discuss possible collaboration with the Sweden Democrats, a position that departs from the arrangement of a 'cordon sanitaire' whereby all parties have so far agreed not to engage with what is seen as an unacceptably racist party.

The Sweden Democrats continue in opposition, but they must fit into a parliamentary system and so are organized as a party rather than a movement. In this regard, they fit the pattern of other European populists. Yet they also confront a unique situation in relation to the media: Swedish media regulation prohibits disclosing the religious or ethnic or other background of those who perpetrate crimes in the media unless they are relevant. This has given alternative online 'newspapers' the opportunity to do so since they are not subject to the same laws, with the result that these 'newspapers' thrive on publishing stories that present Sweden as a country that is threatened by immigrant crime. Another prominent theme in these alternative media and in Sweden Democrat self-presentations is opposition to a multicultural or 'politically correct' agenda of the elite establishment - as in the US and other right wing populist parties and movements.

The Sweden Democrats are foremost an anti-immigrant party. Immigrants are held responsible for criminality. But there is also a wider anti-Islamist agenda, which has led the Sweden Democrats to take a strong pro-Israel stance in foreign policy, an about turn for an erstwhile anti-Semitic neo-Nazi party (Tamas 2016). And like other European right wing populists, they support a tough 'law and order' stance. But they also portray themselves as defenders of the Swedish welfare state (the 'folkhem'), which is the core left-wing political tradition in Sweden in the $20^{\text {th }}$ century embodied in the dominant Social Democrat party. Sweden Democrats claim 
this mantle and seek to maintain or increase benefits particularly for the elderly, but they want to restrict them to 'true Swedes'; in other words, excluding immigrants.

The Sweden Democrats thus belong squarely in the 'my country first' or 'my people first' family of right-wing populism: they rail against cosmopolitan elites and seek to put boundaries around a group of those whose citizenship - civic, political, and social - should be protected as against those who should be excluded from citizenship. They advocate a mild economic protectionism, for example to safeguard national natural resources, and want to strengthen a common culture as the basis for citizenship. Sweden Democrats have seized on cultural qualifications for citizenship, demanding language and culture tests for those who should be included in the 'peoples' home'.

The Sweden Democrats can be locked out of power by a coalition of left and right parties or by stealing their thunder by implementing strong immigration controls. In Norway and Denmark, right-wing populists have been brought into the fold of coalition governments (Lindroth 2016). But in Sweden their position of being 'locked out' also reflects a growing split in popular opinion: While the supporters of other parties have become more positive towards immigration and refugees, Sweden Democrat supporters have hardened their position (Rydgren and van der Meiden 2016). The same goes for trust in the media: while this has remained stable among the population as a whole, among Sweden Democrats, there is a growing distrust of the media (Demker and van der Meiden 2016). And since support for Sweden Democrats also comes from voters who are otherwise likely to vote for the Social Democrats and who have traditionally benefitted from the citizenship of those in the 'peoples' home', as well as from conservatives, they are beyond left and right which gives them their lynchpin position. Like the other populists examined here, it is not just the 'left behind' or those 
facing economic status anxieties: Sweden Democrats want to protect citizenship rights in the 'peoples' home' which 'the establishment' is supposedly failing to do.

\section{Interstitial Emergence of a Deep Seam in American Culture}

Populism has far deeper roots in the US than in Europe, where populist parties have only won power since the 1990s. The history of American populism can be traced to independent farmers in the mid-West in the late $19^{\text {th }}$ century (Kazin 1998). These roots are still in evidence in the rural bias of Trump voters (Cramer 2016). Trump's anti-statism also has deep roots in American society, and conspiracy theories are only the extreme expression of this (Hall and Lindholm 2011, pp. 109-20). What is distinctive about American populism compared to populism in Europe and elsewhere is that it was until recently movement-based because no populist (or other third) party was able to break the lock on the power of the two dominant parties at the national level.

Trump emerged 'interstitially', firing up supporters during his election campaign against the 'establishment' Republican Party. He drew on support from the Tea Party movement which had supported Republicans on the extreme anti-statist right wing of the party (Skocpol and Williamson 2012). But his position also departs from the Tea 'Party' and from the traditional right wing position of an anti-tax and anti-big government and pro-market movement (Mudde 2017). Trump supports not just infrastructure spending but also economic protectionism and (like the Sweden Democrats) more state benefits for the 'deserving' and less for the 'undeserving', which taps into a deep seam of 'nativism' (or ultranationalism) in the US. Trump has also focused on illegal immigration and on Islamic terrorism and favours strong law and order policies. 
Trump's foreign policy during his presidential campaign and since has combined an aggressive militarism with a retreat from the international liberal order (which was long regarded as the dominant foreign policy among American elites, see Ikenberry 2011) insofar as others should bear its cost (Smith 2016). This is in line with a protectionist or economic nationalist policy, which now pits globalizers against anti-globalizers (Campbell 2018, p. 152). These 'my nation' or 'my people first' ideas, again, are deeply rooted in American public opinion but they have not been the mainstream political ideas among the elite. Mudde (2017) has pointed out that in relation to domestic policy, Trump appeals to the more right-wing populist base of the Republican party which is also often more prominent at the local and state levels against the more moderate national party leadership. Yet more than half-way through his first term after the mid-term elections, Trump's populist stance has been adopted by an increasing number of prominent national Republican figures.

Still, without an organized party, American populism reflects the incoherent or fragmented state of American politics in which two parties alternate but which are also by some measures out of tune with a large portion of the electorate. Some scholars (Claggett, Engle and Shafer 2014) have argued that there has been long-standing public support for a populist political agenda which has remained hidden by public opinion measurement that focuses on support for two parties. There is also an extreme right or white nationalist movement that supports Trump's agenda, the most prominent of which has become known as the 'alt-right'. As Hawley (2017) documents, this is mainly an online movement outside of the mainstream media. He argues that although the alt-right did not secure Trump's victory, they were vocal and enthusiastic supporters. And this extreme right has reshaped the Republican party insofar as it can field populist candidates that support a radical right-wing agenda against more moderate Republicans. 
The weakness of the alt-right movement is that it is not organized, except via the informal channel of certain extreme candidates, individual journalists and intellectual figures. But Trump secured the nomination of the Republican party, and so secured power via an established party. Yet as Mudde points out, unlike European right-wing populists who have come to be institutionalized in - and led by - parties, in the US, the 'party system' is 'dominated by two stable, but weakly centralized and organized, political parties' $(2017$, p. 48). This weakness of parties makes the US a fragmented or log-jammed political system overall. Hence too Trump's position since becoming president has been to continue to antagonize his own party ('the establishment') and the opposing party (though opportunistically making alliances with the Democrats as necessary) and to balance various more and less populist factions within his administration and beyond. He can also rely on the support of a part of the electorate as measured in the approval ratings of polls, an otherwise 'silent majority' (on the right) of a President beleaguered by a hostile media and political establishment. But this base is stridently represented in an online and intellectual movement which may be more extreme than most Trump supporters and by politicians on the populist-supporting right wing of the Republican party. As Mudde (2017) points out, this fringe is part of a wider drift rightwards that is increasingly becoming the mainstream.

As in the other three cases, Trump's supporters are curiously a 'majority' that has come to feel threatened by a 'minority' (Kaufmann 2018). This 'majority' is in fact a volatile base of public support for a 'my people first' agenda against cosmopolitan elites. Populists here seek to restrict the benefits of citizenship to 'the people', again vaguely defined but with a long and deep history in American nativism and authoritarian-leaning politics. Uniquely in the US - though we will see similarities with India - the success of American populism is due to a single leader 
now increasingly supported by an initially reluctant party with its electoral base and with the help of a wider social and intellectual movement. Populism is a growing faction in a logjammed regime with a politics that is fought out in the media for the public's support against the backdrop of a highly pluralistic and fragmented civil society. Whether it can maintain or gain even more power within the American political system is not known.

\section{A Populist Leader Spearheads Hindu Nationalism}

In 2014, the BJP (Bharatiya Janata Party), a Hindu nationalist party, won the first absolute majority in Indian elections since 1984. It strengthened its position in the 2019 election. Narendra Modi's campaign was unabashedly anti elite. He became the leader of its party and candidate against the opposition of the establishment of party elders that dominated within the party (Price 2016). His campaign also took aim at the mainstream establishment media, in this case, the English-language elite media. Once he had become the BJP's leader, he waged a campaign which appealed directly to the electorate, also via media rather than relying on his party organization (Rajagopal 2016). His victory and the continued strong support for his populist agenda as prime minister have reshaped Indian politics.

Modi is not the only populist challenger: the Aam Adhmi party has had also had some local support, especially in the Delhi municipal government, with its left-wing populist antiestablishment and anti-corruption message. There are further parallels with the US which, like India, has a highly decentralized political system. Hence, as in America, there is also non-BJP regional support for populism that is not centred on Modi (Subramanian 2007). There are also regionally strong forms of populism (Jaffrelot and Tillin 2017). For example, Wyatt (2013) documents populism in Tamil Nadu and its Dravidian nationalist parties, which have adopted 
the strategy that is typical of Indian populist parties of give-aways to loyal supporters, including televisions and cheap rice (which make this type of populism close to 'clientelism'). This strategy, as Wyatt notes, regards citizens as consumers as well as welfare recipients ('paternalist populism'). He also points out that in this case, the ruling populist party has promoted a technocratic agenda of economic welfare on behalf of the (Dravidian) people against a self-enriching dynastic political elite, perhaps with echoes of earlier Latin American populisms.

Palshikar (2015) has argued that the Hindu nationalist ideology that used be a social movement or a fringe within the BJP has moved to the center; it has become mainstream in a majoritarian democracy. Indian populism is ethno-religious, but the main perceived threat in this case comes from Muslims within rather than from external forces (as in the US and Sweden and in Europe generally). Hindus stir up fears about the Muslim population which is regarded as fomenting violence and experiencing faster population growth than the Hindu majority. Hindu nationalists also promote the idea that an increasingly secular or multicultural state is weakening India's Hindu identity.

In India, all parties draw on support from among specific ethnic and religious groups. But while other major parties seek support across religious or cross-caste boundaries to attract a wider base of voters, the BJP appeals specifically to those who want to revive the greatness of Hindu civilization. In India, populism has taken the form of Hindu nationalism, but that is a label that must be used carefully insofar as the Congress party which dominated Indian politics into the 1980s also bore the nationalist anti-colonialist mantle. The BJP's nationalism, in contrast, has grown out of a more extreme form of ultranationalism that also excludes 'others'.. Jaffrelot (2016) has traced the origins of the Hindutva agenda to its affinity with German and European 
fascist ideas of the 1920s and 30s. But he notes an important difference, which is that Hindu nationalist thought was oriented more to restoring the greatness of Hindu religious culture rather than a racial one as with the Nazis. Another contrast with fascism is that Hindutva thinkers were more interested in a longer-term project of creating a 'new man' and a national culture rather than seizing state power. The early history of the Hindutva movement cannot be traced in detail here, but it gathered strength in the 1980s and 90s around a series of conflicts (Hansen 1999). And as a party, the BJP only took off in the late 1990s.

Hindu-Muslim ethnic conflict has waxed and waned over the course of India's history, but it has recently crystallized as support for the BJP has replaced the previous national-level dominance of the Congress party. One reason for this shift is that the BJP has been able to focus the attention of Hindus on 'threats' from Muslims. Parties in India are weakly institutionalized in the sense that they do not rest on strong and stable relations with unions or other socio-economic groups (see also Kenny 2017), and their support bases with different ethno-religious (or caste) groups have shifted over time. Indian parties have relied more than elsewhere on clientelist patronage, promising groups economic benefits or political appointments or preferment, which has benefitted not only the BJP but also other populist parties. But at the national level, the support which has come to have the broadest appeal is anti-Muslim and pro-Hindu sentiment.

Hansen (1999, pp. 229-34) has documented that Hindu nationalism is also an economic nationalist movement against globalization, including 'patriotic consumption' of native and 'pure' goods associated with a Hindu heritage instead of 'contaminated' Western goods. And Indian populists can also point to external enemies, focused mainly on the conflict with Pakistan and Bangladesh that has simmered since India's partitions - rather than, as in the 
Chinese case, on the war against colonial powers or on wars past (particularly with Japan). There is also a vaguer Western enemy which does not give Indian civilization its rightful place in the global pecking order, though as in China, this harking back is mixed with a recognition that a 'high-tech' future is necessary for India to (re-)gain this rightful place. Jaffrelot (2015) thus calls Modi a high tech populist since he painted a bright future for a digital India leading the world - just as Xi heralds the dream of China leading the world.

\section{Asserting China's Place in the World}

The label 'populism' does not quite fit the Chinese case because the regime is authoritarian; so direct criticism of the establishment or of the political elite (the party) is not tolerated. But the government also needs to be at least somewhat responsive to different groups in society (though it can repress them in the end), lest it lose their support. And in this case, anti-elitism is aimed against those parts of the elite that do not express enough 'China first' sentiment. This antielite sentiment takes a variety of directions. Prominent among these is Han nationalism, but another direction harks back and seeks to revive the greatness of China's communist era. A third aims to reassert the place of ancient or traditional Chinese civilization in the world at large. All three seek to restore China's greatness. Han nationalism, 'nostalgic' communism, and Chinese civilizationism all have intellectual movements backing them at the same time that intellectuals are excluded from publicly disseminating an ideology that departs from party orthodoxy. But intellectuals have nevertheless competed for the pre-eminence of these rival worldviews among themselves (Xu 2001), and the regime has also sought to harness all three ideologies to promote Chinese greatness and uses these informal movements to bolster its own legitimacy - as long as they stay within certain bounds. 
Unlike in the other three cases then, populism is not a force that seeks rights that can be represented - democratically - in the state. Yet apart from intellectual circles, there is also strong and widespread popular support for - again, all three - versions of re-asserting Chinese greatness and its global pre-eminence. The recent origins of Chinese populism are in the 'mass line' campaigns (Tang 2016), but also in anti-colonial or anti-imperialist nationalist mobilization, which some argue outweighs communism in shaping modern Chinese politics (Wu 2007). As in India, throwing off the yoke of the West (and of Japanese imperialism) means that foreign relations have played a major role in populism. Grassroots mobilization targets elites that are insufficiently aggressive towards foreign enemies or elites that are too cosmopolitan. Wu says that this grassroots movement will ultimately either become part of the regime or it will remain a separate and oppositional social movement. But in this regard the options facing Chinese populists are not different from those in the other three cases.

Populism in China has traditionally been concerned with maintaining an orderly society, with the public demanding from rulers that the state should ensure stability and highly moral conduct - and vice versa. One example of this effort has been in bolstering the legal system during the reform period. Initially, the aim was to bring law closer to the people, which includes seeking the inputs or wisdom of people in shaping law (Liebman, 2011). More recently, law has become more professionalized, but the aim is still to make law more responsive to local needs. It should be noted that there is no contradiction between strengthening the rule of law and populist authoritarianism since, unlike in the West, law is not seen as preserving individual rights as much as it is a means for the state (via the party) to direct society and vice versa (Tang 2016).

Tang documents how this 'populist authoritarianism' is part of a long-standing tradition of campaigns that mobilize people on behalf of different goals. As in other regimes, he argues, 
the party relies on public opinion and the regime's 'legitimacy lies in the claim that they represent the interest of the majority'(2016, p. 158). The state is therefore strengthening the means whereby it can gauge public demands. This includes policy experimentation which is aimed at making local authority more responsive to peoples' needs (Heilmann 2008). Similarly with populist anti-corruption drives, which are promoted as long as they serve the party's aims. As Hassid (2015) points out, however, responsiveness to pressure from below can be a doubleedged sword. For example, when people call for harsh sentences for high-profile criminal or corrupt activity, the state may be inclined to respond vengefully by inflicting popular punishment on innocent people. Chinese populism is therefore not just 'instrumental', fostered from above to bolster the regime. Nor is it a volcano waiting to erupt from below (Whyte 2010). $\mathrm{Wu}$ (2007) says that it is a grassroots movement, rather than being instigated by the regime, which is how the outside world perceives it. It is a deeply rooted current within Chinese society that has recently become amplified, but must also be kept within bounds.

Although populism can be marshalled against foreign enemies and responded to locally, the main thrust is to make the Chinese nation great again. Confucianism is one strand of reviving Chinese civilization. The Han clothing movement, a group that celebrates traditional Chinese culture by wearing clothes that restore Han ethno-religious greatness, is just one example of an attempt to restore Chinese greatness (Carrico 2017). Han nationalism, as Carrico points out, is directed against the elite inasmuch as the government is perceived to suppress the Han majority in favour of 'barbarian' minorities. Yet the regime gives the Han nationalist movement more leeway than other social movements as long as it serves the government's aims to do so. Nationalist protest, as Wright (2018) has argued, has been the most successful among the various types of popular protest against the regime - which for her include environmental, property-related, labor, ethnic, and rural protests - because it often 
strengthens rather than weakens the legitimacy of the regime. This kind of nationalism can also constitute a form of political engagement that is separate from criticism of the regime: love of one's country among young people in particular, as Liu (2012) points out, is greater than their feelings about the government, which they are often indifferent towards.

A different group seeking to revive Chinese greatness is 'New Left' nationalism, which harks back to a time when virtuous communist officials served the people in creating a utopia and 'the people' became entitled to what Andreas (2019), as noted earlier, calls 'industrial citizenship'. He says these rights of industrial workers have risen and fallen in China, and Bo Xilai (a powerful leader in the early 2000s) can be seen as an example of a champion of industrial workers' rights who sought to strengthen these rights against opposition from other elite factions (Blanchette 2019: 104-26). China's 'mass line' popular mobilization sought to legitimize the party by claiming that the party was uniquely placed to translate the wisdom of the masses into policy. During the turmoil of the Cultural Revolution, this mode of legitimation got lost in factional struggles, but this link between the party and the masses resumed during the Reform period. And since 1989, such nationalist sentiment has increasingly moved into the vacuum created by the retreat from the virtues of communism. It can be seen as leaning more closely to the economic nationalism or left-leaning populism that has discussed in the other cases.

This variety points to the fact that, in the absence of a 'people' ranged against a single state elite, it is therefore necessary to identify several 'people' and 'elites': In the pre-modern period, the 'people' were the peasants who would petition the emperor for justice and for their welfare. During communism, they were the working class whose common sense or wisdom should guide the party. During the reform period, they have been those left behind by growing 
inequalities and outraged by the corrupt officials who have unjustly gained from the reforms. Throughout, there have been those who want to revive the Han and Confucian nationalist traditions or the Maoist egalitarian one. It is easy to recognize a struggle to widen the citizenship rights of the 'virtuous' people here, but also easy to recognize the duty of ruling strata to embody an ethic that responds to this virtue or that can be chastised if it fails to do so.

As for the elites that populists now rail against, they are often local officials when it concerns matters of social welfare and justice grievances. But they are the national leadership when it comes to not standing up to 'foreign' enemies, externally and within. This includes the West and the US and Japan and Islamists (including in Western China), but also cosmopolitan factions among political and intellectual elites who fail to stand up to these enemies (Zhang 2019). If we add left-wing populists, these factions include the capitalist 'free market' elites or Westernizing elites allied with foreign influences. But these forces remain informal and fragmented. Hence Chinese populism or nationalism is expressed more online than elsewhere because this movement cannot openly voice organized opposition (Wu 2007). And because it is informal and 'underground', it waxes and wanes in relation to major events, such as corruption scandals or the Beijing Olympics or heightened international tensions with Japan or other foreign powers. Whether populism threatens the regime or emboldens it remains to be seen.

\section{Commonalities and Differences}

The right-wing populist ascent to power in India and the US and their representation in the Swedish parliament represent the single greatest political change in these three countries in the last quarter century. In China, right-wing nationalist populists rank among the greatest threats 
to the stability of the regime alongside protests due to rising inequality. Both right-wing and left-wing populism have been aimed against economic globalization (or neoliberalism) and in favour of economic nationalism. This includes protecting national workforces (social citizenship) and giving preference to restrictedly defined co-nationals as well as safeguarding national resources against their alleged usurpation by other nations (Ivaldi and Mazzoleni 2019). Unlike left-wing populists, right wing populists are not against economic elites as such - except insofar as they champion the politics of global open economies and trade at the expense of the 'people'. Right-wing populists also rail against government officials and employees who secure benefits for themselves or who favour 'minorities' while 'the people' lose out from their policies. Enemy elites include cosmopolitan academics and media professionals who advocate a less national and more diverse culture.

Yet even if 'my country first' or 'my people first' populism goes against internationalism, this has a different significance in the four cases: it is associated with secularism and Western imperialism in India, with the Western- or American-led order in China, with an open and international liberal order upheld by the US which bears too much of its costs, and with multicultural tolerance in Sweden. The timing of populism has also been different. In the US and Sweden, the recent right wing populist ascent started with anti-tax populism during the 1980s and 90s. In China and India, it started with anti-corruption drives in the 90s, though arguably there were earlier strains with Indira Gandhi's emergency and China's 'mass line' ideology. But in terms of the state- and politics-centric account of populism here, these beginnings can be tied to different stages in political development: China and India do not yet have a state that penetrates deeply into society (or what Mann calls 'infrastructural power', 2013) and political elites still have more power to enrich themselves. Such corruption is not an issue - except at the margins - for the US and Sweden, where the lack of responsiveness of 
elites to 'people' is of greater importance. Populism can therefore be seen as part of longerterm drive or of globalizing processes whereby ever greater responsiveness is demanded from the state and its elites 'from below'. This process has accelerated as the limits to growth after the post-war 'Golden Age' have become more visible and constraining (removed for review).

In all four cases, the rise of right wing populism is not pushed by the 'supply side' of parties and leaders but rather pulled by the 'demand side' or 'from below'. In the US there has been public opinion support for populism at least since 1960s (Claggett, Engle and Shafer 2014), but this support only translated into electoral success in 2016 when anti-elitism seized a political opening. In Sweden, an anti-state populist tax revolt fizzled in the early 90s, and a populist party only gained entry into parliament in 2010 and strengthened its representation in 2014 when elites could be blamed for an influx of immigration. The roots of populism in India can be traced to Indira Ghandi's 'state of emergency' and to Hindu-Muslim antagonism from the 1980s onwards and the BJPs electoral victories in the 1990s, but Modi only became prime minister in 2014 when his position in the BJP was such that he could mobilize enough support among the public against the elites in his own party. And in China, populism has been episodic since the 1990s but not very visible because there has been no unified and lasting political organization or faction to carry it. Still, there are constant informal right-wing populist groups and loose-knit elite factions below the surface, but the lid has been kept on so far. Even if populists have only recently come into power in India and the US and have reshaped politics in Sweden and in China, they have been slowly building strength because of longer-term changes - above all in the balances of political power.

Strong states can contain (Sweden) or suppress and harness (China) populists, but in democracies with majoritarian systems (India and the US) and volatile electorates, they can 
become dominant. It has been pointed out (Mudde and Kaltwasser 2017) that populism can be a threat or a corrective to democracy. As long as populists do not undermine or abandon democracy, their demands must be accommodated or vanquished or contained by means of compromise, except where they can be suppressed by authoritarian means. And in China, since the elites that are the target of anti-elitism do not overlap with each other or with the central party leadership, the regime is stable. But keeping criticism averted from party leaders may not last. And the non-overlap in the Chinese case also points to how, in the other cases, anti-elitism similarly aims at some elites rather than others: 'Wall Street' is not 'Washington', and the Gandhi 'dynasty' is not the whole of the Congress party. In Sweden, the multicultural media elites are not the same as the Social Democrat party, even though the Sweden Democrats often conflate them as a left-wing elite.

\section{Right-Wing Populism and its Prospects}

Right-wing populists go beyond the traditional right/left divide of political power. The traditional right consists of market liberals and cultural liberals at one end and cultural conservatives and nationalists at the other. The left is split into labour and welfare protectionists at one end and those who seek state support for diverse and disadvantaged groups at the other. Each of these four groups is at odds with the others. But populism straddles the 'nation-first' positions on the left and the right and its support bases also cut across supporters of traditional right and left parties. Mann's idea of 'interstitial emergence' (1986: 16) has been instanced here in relation to Trump, whereby a new ideology has come about in the space opened by opportunities for appealing to a new support base that was not catered to by traditional Republican and Democrat politicians. But interstitial emergence could equally apply to the 
emergence of a novel ideology beyond left and right in the other three cases where these ideologies have also seized new openings and drawn on new bases of support.

An explanation focused on political power and citizenship rights can therefore also contribute to the debate about whether populists are authoritarian and anti-liberal or democratic (Mounk, 2018). As for populism being anti- or illiberal, Stavrakakis and Jäger (2018) criticize the prominent theories of Mueller (2016) and Mudde and Kaltwasser (2017) as an outdated Cold War opposition between liberal and authoritarian regimes which may have fit the US in a bygone era. Illiberal pluralism also does not fit the cases examined here which include an authoritarian regime (China), attacks on pluralism within a primarily social rather than liberal democracy (Sweden), and India's imperfect liberalism. The citizenship approach suggested here has avoided this opposition, focusing instead on political forces 'from below' including a geopolitical ('outside-in) dimension of when and why these forces are activated. Thus the citizenship explanation offered here is also more than monocausal; combining multiple factors that are longer- and shorter-term. But along with those who think that populists are democratic, we have seen that populism can be seen as the extension of a longer-term project to democratize the state via the expansion of rights. However, this expansion is also moving in a retrogressive direction, by seeking rights for fewer rather than more groups, and to expand them for some while curtailing them for others.

Like other social movements in the past, populists are mobilizing to secure more rights from the state. Political elites can be responsive to this mobilization or they can resist it and be responsive to other demands - such as demands for universal citizenship or to extend social rights more inclusively, including to immigrants. The populists' drive for democratization is therefore distinctive inasmuch as populists do not seek an enlargement of rights from the state 
(or only for some) and they also criticize cosmopolitan elites for being too generous with rights (for 'others'). In modern democratic states, it is inappropriate to deny people within a territory their civil and political rights (China also has such rights, albeit of a different kind and often in-name only, enshrined in Chinese law). Social citizenship rights are somewhat different from civil and political ones since they are continuous rather than discrete and oftentimes subject to resource constraints (Mann's collective power) rather than zero-sum distributive power (the indivisible power of A over B; Mann 1986: 6). At the same time, social citizenship rights, like civil and political ones, arguably have the greatest legitimacy when they are universal.

Whether the resources become available and elites are responsive by distributing them in a way that meets populist demands remains to be seen. The same goes for free trade and open markets and the impartiality of media; whether these withstand economic nationalism or criticisms that the media are partial against putting 'my country' or 'my people first' are open questions. The same goes for how plural powers and open borders can be maintained in the face of demands for prioritizing the rights of a 'virtuous' people. Will populists' quest to expand citizenship rights for some at the expense of others continue to strengthen or weaken? This larger question encompasses the others, but requires taking the forces that give rise to populists' seriously.

\section{References}

Andreas, J. 2019. Disenfranchised: The Rise and Fall of Industrial Citizenship in China. New York: Oxford University Press.

Baas, D., 2014 (2nd ed.). Bevara Sverige Svenkst. Ett Reportage om Sverigedemokraterna. Stockholm: Bonniers. 
Bardhan, P., 2010. Awakening Giants, Feet of Clay: Assessing the Economic Rise of India and China. Princeton: Princeton University Press.

Blanchette, J. 2019. China's New Guard: The Return of Radicalism and the Rebirth of Mao Zedong. New York: Oxford University Press.

Brubaker, R., 2017. Why Populism, Theory and Society, 46: 357-385.

Campbell. J.,2018. American Discontent: The Rise of Donald Trump and the Decline of the Golden Age. Oxford: Oxford University Press.

Carrico, K.,2017. The Great Han: Race, Nationalism, and Tradition in China Today. Berkeley: University of California Press.

Clagett, W., Engle, P. J. and Shafer, B. 2014. The Evolution of Mass Ideologies in Modern American Politics, The Forum, 12(2): 223-256.

Collins, R., 1999. Maturation of the State-Centred Theory of Revolution and Ideology, in his Macro-Sociology: Essays in Sociology of the Long Run. Stanford: Stanford University Press, pp.19-36.

Collins, R., 2006. Mann's Transformation of the Classical Sociological Traditions, in J. A. Hall and R. Schroeder (eds), An Anatomy of Power: The Social Theory of Michael Mann. Cambridge: Cambridge University Press, pp. 19-32. 
Cramer, K., 2016. The Politics of Resentment: Rural Consciousness in Wisconsin and the Rise of Scott Walker. Chicago: University of Chicago Press.

Crouch, C. 2004. Post-Democracy. Cambridge: Polity Press.

Demker, M. and Van der Meiden, S., 2016. Allt starkare polarisering och allt lägre flyktingmotstånd in Ohlsson, J., Ekengren Oscarsson, H. and Solevid, M. (eds.) Ekvilibrium. Gothenburg: Göteborgs universitet: SOM-institutet, pp.197-214.

Fukuyama, F., 2018. Identity: Contemporary Identity Politics and the Struggle for Recognition. London: Profile Books.

Gellner, E. 1983. Nations and Nationalism. Oxford: Basil Blackwell.

Gidron, N, and Bonikowski, B., 2013. Varieties of Populism: Literature Review and Research Agenda, Weatherhead Working Paper Series, No. 13-0004; available at http://scholar.harvard.edu/gidron/publications/varieties-populism-literature-review-andresearch-agenda (last accessed 7.11.2016).

Gidron, N, and Hall, P., 2017. The Politics of Social Status: Economic and Cultural Roots of the Populist Right, British Journal of Sociology, 68: S1: 57-84.

Hall, J, and Lindholm, C., 2001. Is America breaking apart?. Princeton: Princeton University Press. 
Hansen, T., 1999. The Saffron Wave: Democracy and Hindu Nationalism in Modern India. Princeton NJ: Princeton University Press.

Hassid, J., 2015. China's Responsiveness to Internet Opinion: A Double-Edged Sword, Journal of Current Chinese Affairs, 2: 39-68.

Hawley, G., 2017. Making Sense of the Alt-Right. New York: Columbia University Press.

Heilmann, S., 2008. Policy Experimentation in China's Rise, Studies in Comparative International Development, 43: 1-26.

Heiskala, R., 2018. For a holistic social science: the NACEVP model applied to the environment, gender and populism, Journal of Political Power, 11:3, 322-340.

Ikenberry, G. J., 2011. Liberal Leviathan: The Origins, Crisis, and Transformation of the American World Order. Princeton NJ: Princeton University Press.

Ionescu, G., and Gellner, E. (eds.) 1969. Populism. Its Meanings and National Characteristics. London: Weidenfeld \& Nicolson.

Ivaldi, G. and Mazzoleni, O., 2019. Economic Populism and Producerism: European RightWing Populist Parties in a Transatlantic Perspective, Populism, 2: 1-28

Jaffrelot, C., 2015. The Modi-centric BJP 2014 election campaign: new techniques and old tactics, Contemporary South Asia, 23(2):155-61. 
Jaffrelot, C., 2016. The Hindu nationalist strategy of stigmatisation and emulation of 'threatening Others': an Indian style fascism?, in Koenig, L. and Chaudhuri, B. (eds), Politics of the 'Other' in India and China. Western Concepts in Non-Western Contexts. Abingdon: Routledge, pp.17-30.

Jaffrelot, C, and Tillin., 2017. Populism in India, in Kaltwasser, C.R. et al. (eds). The Oxford Handbook of Populism. Oxford: Oxford University Press. DOI: 10.1093/oxfordhb/9780198803560.013.7

Judis, J., 2016. The Populist Explosion: How the Great Recession Transformed American and European Politics. New York: Columbia University Press.

Judis, J., 2018. The Nationalist Revival: Trade, Immigration, and the Revolt Against Globalization. New York: Columbia University Press.

Kaufmann, E., 2018. Whiteshift: Populism, Immigration and the Future of White Majorities. London: Allen Lane.

Kazin, M., 1998. The populist persuasion: An American history. Ithaca: Cornell University Press.

Kenny, P., 2017. Populism and Patronage: Why Populists Win Elections in India, Asia, and Beyond. Oxford: Oxford University Press. 
Liebman, B., 2011. A Return to Populist Legality? Historical Legacies and Legal Reform, in

Heilmann, S. and Perry, E. (eds), Mao's Invisible Hand. Cambridge MA: Harvard University Press, pp.165-200.

Lindroth, B., 2016. Vaeljarnas Haemnd. Populism och nationalism i Norden. Stockholm: Carlsson.

Liu, F., 2012. 'Politically indifferent' nationalists? Chinese youth negotiating political identity in the internet age, European Journal of Cultural Studies, 15(1): 53-69.

Mair, P., 2013. Ruling the Void: The Hollowing of Western Democracy. London: Verso.

Malesevic, S. and Haugaard, M. (eds.) (2007). Ernest Gellner and Contemporary Social Thought. Cambridge: Cambridge University Press.

Mann, M., 1988. Ruling Class Strategies and Citizenship, in his States, War and Capitalism. Oxford: Basil Blackwell, pp.188-209.

Mann, M. 1986. The Sources of Social Power, Volume I: A History of Power from the Beginning to 1760 AD. Cambridge: Cambridge University Press.

Mann, M., 2013. The Sources of Social Power vol.4: Globalizations 1945-2011. Cambridge: Cambridge University Press. 
Moffitt, B., 2017. The Global Rise of Populism: Performance, Political Style, and Representation. Palo Alto: Stanford University Press.

Mounk, Y., 2018. The People vs. Democracy: Why Our Freedom Is in Danger and How to Save It. Cambridge MA: Harvard University Press.

Mudde, C., 2007. Populist Radical Right Parties in Europe. Cambridge: Cambridge University Press.

Mudde, C., 2017. The Far Right in America. London: Routledge.

Mudde, C. and Kaltwasser, C. R., 2017. Populism: A Very Short Introduction. Oxford: Oxford University Press.

Mueller, J-W., 2016. Was ist Populismus? Ein Essay. Frankfurt: Suhrkamp.

Palshikar, S., 2016. Who is Delhi’s Common Man?, New Left Review, 98: 113-28.

Pontusson, J., 2005. Inequality and Prosperity: Social Europe vs. Liberal America. Ithaca: Cornell University Press.

Price, L. 2016 (2nd ed). The Modi Effect: Inside Narendra Modi's campaign to transform India. London: Hodder. 
Rajagopal, A., 2016. The Rise of Hindu Populism in India's Public Sphere, Current History, April, pp. 123-9.

Rydgren, J. and Van der Meiden, S. 2016. Sweden, Now a Country Like All the Others? The Radical Right and the End of Swedish Exceptionalism, Stockholm: Department of Sociology Working Paper Series.

Skocpol, T., and Williamson, V., 2012. The Tea Party and the Remaking of Republican Conservatism. Oxford: Oxford University Press.

Smith, D., 2016, Populism, Nationalism, and U.S. Foreign Policy, in M. Golder and S. Golder, eds., Comparative Politics Newsletter: The Organized Section in Comparative Politics of the American Political Science Association, 26(2): 101-6.

Stavrakakis, Y. and Jäger, A., 2018. Accomplishments and limitations of the 'new' mainstream in contemporary populism studies. European Journal of Social Theory. 21(4): 547-65.

Subramanian, N., 2007. Populism in India, SAIS Review of International Affairs, 27(1): 81-91.

Tamas, G., 2016. Det Svenska Hatet. Stockholm: Natur \& Kultur.

Tang, W., 2016. Populist Authoritarianism: Chinese Political Culture and Regime Stability. New York: Oxford University Press.

Turner, B. 1986. Citizenship and Capitalism. London: Allen and Unwin. 
Walby, S. 2009. Globalization and Inequalities: Complexity and Contested

Modernities. London: Sage.

Whyte, M., 2010. Myth of the Social Volcano: Perceptions of Inequality and Distributive Injustice in Contemporary China. Stanford: Stanford University Press.

Wright, Teresa. (2018). Popular Protest in China. Cambridge: Polity Press.

Wu, X., 2007. Chinese cybernationalism: Evolution, characteristics, and implications. Lanham MD: Lexington Books.

Wyatt, A., 2013. Populism and politics in contemporary Tamil Nadu, Contemporary South Asia, 21(4): 365-81.

Xu, B., 2001. Chinese Populist Nationalism: Its Intellectual Politics and Moral Dilemma, Representations, 76: 120-40.

Zhang, C., 2019. Right-wing populism with Chinese characteristics? Identity, otherness and global imaginaries in debating world politics online. European Journal of International Relations. https://doi.org/10.1177/1354066119850253

Zhao, S. 2004. A Nation-State by Construction: Dynamics of Modern Chinese Nationalism. Stanford: Stanford University Press. 